\title{
An Exploration on Kirgiz Shyrdak Techniques in Xinjiang, China*
}

\author{
Xiaoyu Xin \\ College of Textile and Clothing \\ Xinjiang University \\ Urumqi, China 830046
}

\author{
Juan Qian \\ College of Textile and Clothing \\ Xinjiang University \\ Urumqi, China 830046
}

\author{
Aimin Xiao \\ College of Textile and Clothing \\ Xinjiang University \\ Urumqi, China 830046
}

\begin{abstract}
Through field investigation and literature review, this paper conducts a comprehensive study on the production process, pattern art, and cultural connotation of the Kirgiz ${ }^{1}$ peoples' folk appliqué felt blanket "Shyrdak" in Xinjiang, China, and believes that the production process can be divided into floor blanket felting and surface blanket felting two parts. The motifs of the beasts, horns, birds, weapons, mountains and rivers commonly seen in Kirgiz people's daily life are used in its patterns. Patterns are arranged symmetrically with bright colors and rich changes which reflect the profound cultural traditions of Kirgiz people.
\end{abstract}

\section{Keywords-Kirgiz; felt pattern; Shyrdaks}

\section{INTRODUCTION}

"Shyrdak" is the Kirgiz language for "applique felting blanket" and is an indoor felt product commonly used by Kirgiz families. It is mostly spread on the floor of a yurt or a house, and is used as a mat for lying or sleeping. Also it was often used as a tapestry to decorate walls. As an ancient nomad nation, Kirgiz has existed for more than 2,000 years, and felt making has been an important handicraft with the development of the Kirgiz people. Felt products are durable, easy to draw, simple to make, and it is damp-proof, wind-proof, quake-proof, keep warm and other practical properties, for thousands of years it has been a favorite textile material for the nomadic peoples such as Kirgiz, Kazaks, etc. [1]. The Shyrdak is a distinctive household felt product formed by the Kirgiz people through a long period of historical inheritance. It is also an indispensable item for every family to decorate their homes and plays an important role in the daily life of Kirgiz people.

The Kirgiz's Shyrdaks generally uses red, orange, blue, green and other bright, strong color matching, according to the geometric skeleton mosaic composition, thus forming a

*It is a project supported by the National Social Science Fund of China, 2017. (Grant No.17XMZ095).

Kirgiz, one of China's 56 ethnic groups, mainly live in south Xinjiang in China. distinctive decorative feature, with strong nomadic ethnic characteristics. Based on the field investigation of the Kirgiz families in the villages of Tugumaiti and Halajun in the Kezilesu Kirgiz Autonomous Prefecture of Xinjiang, China, this paper analyzes and records of the production process of the Kirgiz Shyrdaks in Xinjiang in order to provide some basis for the protection and inheritance of this folk craft.

\section{PRODUCTION PROCESS OF SHYRDAKS}

A Kirgiz Shyrdak is generally composed of two parts, one is a floor felt blanket made of coarse dark animal hair, and the other is a surface blanket made by quilt dyeing felt. Kirgiz people have learned to sort and use wool of different grades and colors a long time ago. In the production of Shyrdaks, the thick dark wool is generally made into thick floor felt, and the white finer wool is made into a thin white felt and then dyed into a different color of felt to make surface felt. Shyrdak's production process is simply the process of making floor felt and surface felt separately, and finally stitch the floor and the surface felts together to form a complete Shyrdak.

\section{A. Process of Felting Floor Blanket}

The method of making Shyrdak is relatively simple, only roll the dark colored wool such like black, brown, and gray into a dark, thick floor felt according to the required size. Its production method is basically the same as that of other nomads' felt rolling method in Xinjiang. In the Qing Dynasty "Xinjiang Tuzhi" has recorded in details about the felt making method in Xinjiang: "Put the yarrow as a curtain on the ground, wash the wool and pay it on the curtain, use the wicker to make it evenly, simmer with boiling water, and roll it tightly. Or use a donkey or a horse twist it until it forms a felt". [2] It can be seen that the traditional felting process should include washing, loosing up, spreading, heating and humidifying, rolling and shaping and other process. Uighur, Kazak, Kirgiz, Mongolian, Tajik people in Xinjiang all use similar methods for felting. First, the washed wool is laid on a straw and beaten with wicker to make it evenly, then the wool is sprinkled with 
hot water, and the wool is rolled up into a cylinder together with the straw, and is tightly fasten with a rope, and the external force is applied to the wool roll, usually the livestock is used to pull up, or use foot to trample and the elbow to rub repeatedly for one to two hours to shrink the inside wool into a felt blanket, after the curtain is unrolled, the blanket is laid flat, re-humidified and rolled up, continue pressing and shaping, and when finally unrolled the felt the inside wool will form into a flat, dense felt piece [3]. The Kirgiz Shyrdaks floor blanket has different sizes, depends on the area of the user's home. The largest can be up to 4 meters long and 2 meters wide, the smaller ones are 1.5 meters long and 0.5 meters wide, among them the most popular is 3-4 meters long, 1.5-2 meters wide large felt blanket.

\section{B. Process of Felting Surface Blanket}

The surface blanket is generally made of thin fine felt that has been dyed already. It is the essence of Shyrdaks and its pattern, color matching and production process determine the overall appearance of a Shyrdak. From the perspective of the overall layout, the surface felt generally includes the middle main pattern area and the surrounding pattern matching area, which are often separated by white and black wavy strips as shown in Fig. 1. Through research, it is known that the production process of the surface blanket generally includes a series steps such as felting, dyeing, artificial sewing, trimming, and patchwork.

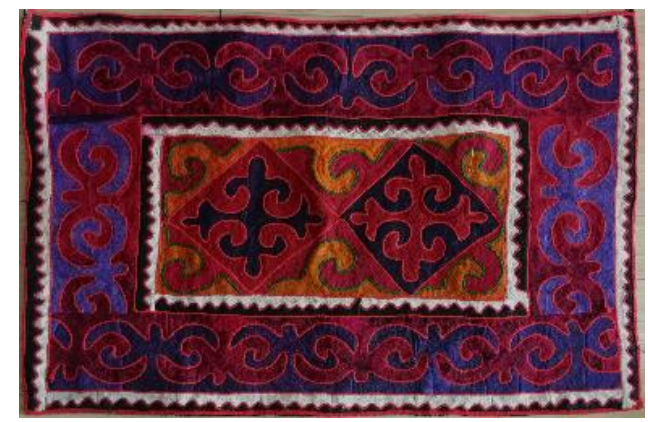

Fig. 1. The overall layout of a Kirgiz Shyrdak's surface blanket.

1) Surface felting: The rolling method of the surface felt is the same like floor felt, except that the original white wool is selected to make into a relatively thin and fine felt piece for the next dyeing step.

2) Dyeing: The Kirgiz people used various mineral dyes or plant dyes such as bark, roots, leaves, husks and petals to dye wool, such as green vitriol, Chinese scholartree, madder, walnut, the flower of red willow,pomegranate, and indigo. These natural dyes are more environmental friendly, but they have limitations in terms of convenience, color diversity, and durability of color fastness. With the development of the market economy, a large number of modern dyes with economic benefits, rich colors, and strong color fastness have flooded into the market, currently most of the Kirgiz people use the chemical dyes purchased in the market for wool dyeing.

The dyeing process is relatively simple. Put the salt and dye into the water after heating. The proportion is depends on the experience of the producer based on the proportion of felt and water. Generally, half basin water for two handful of salt (can also be replaced by wine), two spoons of dye, plus two handful of urea is used as a dyeing agent [4]. After the dyeing liquid is prepared, the original white felt piece that has been rolled is put into the dyeing liquor to make the felt under the liquid. The time of dyeing depends on the amount of the felt, and the dyed felt is shown in "Fig. 2".

The common dyes of the Kirgiz include red, orange, rose, golden, sapphire blue, green and other bright colors. When dyeing the surface felt, the original white felt is normally dyed into a pure-colored thin felt, and the surface felt to make central pattern area is often dyed in whole piece while the felt to make surrounding patterns normally dyed with strips about $30-40 \mathrm{~cm}$ wide. In general, the color of the dyed thin fine felt for use is based on how many colors needed for the surface felt.

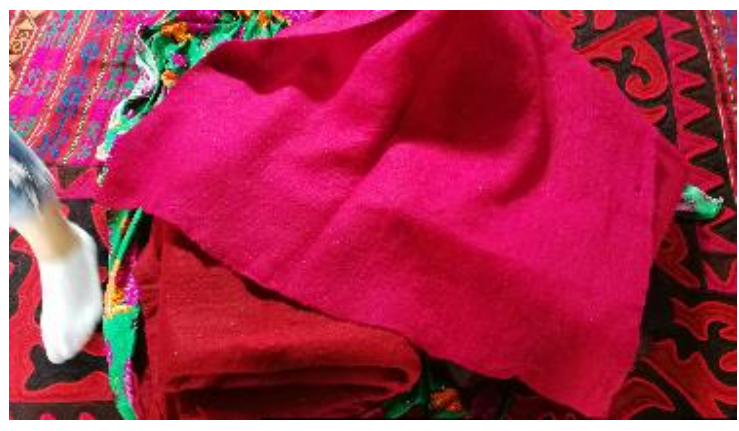

Fig. 2. The dyed thin fine felt.

3) Baste and draw the pattern: The dyed thin fine felts are then individually cut into the desired size, which is the size of the individual pattern unit in the Shyrdak's surface felt. The most common composition form of the Kirgiz Shyrdaks is the rectangular main pattern area in the middle and the striped match pattern area in the periphery. In the main area, square diamonds with a side length of $30-50 \mathrm{~cm}$ are used to form the pattern. Triangles are applied to the outside of the diamond to fit the patterns, while the surrounding areas are mostly use a long strip of $30-40 \mathrm{~cm}$ two-sides continual pattern for composition. Therefore, according to the required size and pattern design, the colored thin felt piece in the main pattern area is generally cut into a square with a side length of 30-50 $\mathrm{cm}$, and the color felt in the pattern matching area is cut into the same length as the overall edge of the piece, $30-40 \mathrm{~cm}$ wide strips. Then the two sharply-contrasted colored felt sheets are basted together with larger stitches, and the preconceived pattern is drawn on them. Kirgiz females make shyrdaks year in year out, so the commonly used patterns are already engraved on their mind. When used, they painted the pattern directly on the colored felt sheet by chalks. "Fig. 3" shows the effect of the a single unite pattern felt colored pattern was drawn by chalks after stitched them. 


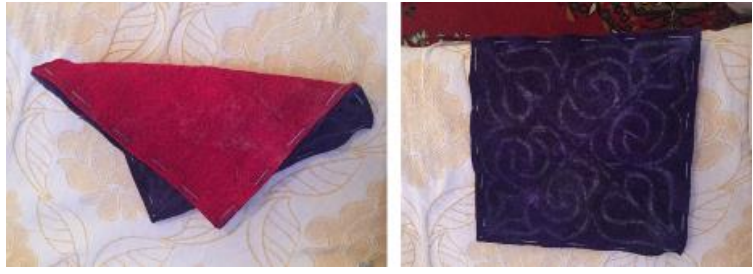

Fig. 3. Baste and draw the single unit pattern.

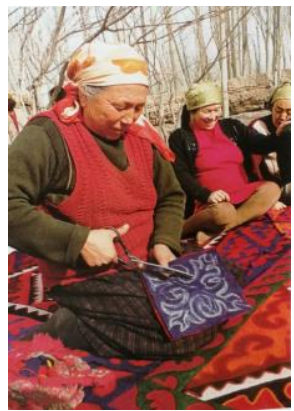

Fig. 4. Cut the single unit pattern.

4) Trim applique: The most important feature of Shyrdaks lies in the patterns and color complementation. They are skillfully inlayed within each other and naturally form a harmonious and unified composition. This mutual inlaying pattern is achieved by simultaneously cutting out a pattern by disposing two pieces of basted felts fixed together with a different-colored felt,as shown in "Fig. 4", and then disassembling each other and combined together, using the pattern of the first color felt to match with the background of the second colored felt. The pattern of the second color felt is matched with the background of the first color felt, and finally form the effect of applique surface. The different colored felt and the background are first temporarily fixed with the yarn stitches, so that two unit patterns with the same pattern and opposite colors are formed, as shown in "Fig. 5" and "Fig. 6". The main pattern area of Shyrdaks is mostly composed of one or more groups of square diamond pattern units. The surrounding pattern matching areas are echoed from up and down, left and right with each other, and the composition forms of applique inlaying are also formed.

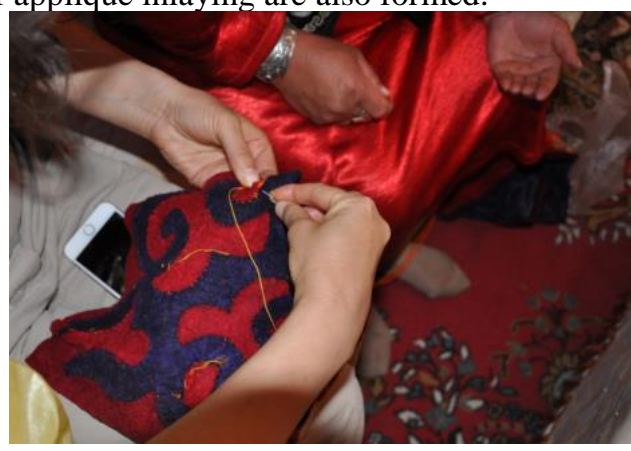

Fig. 5. Fix the two colored felt with yarn.

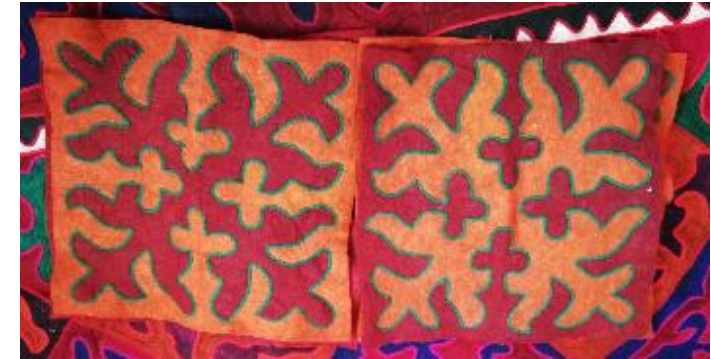

Fig. 6. A pattern unit of applique in main pattern area.

5) Stitching the decorating yarns: After stitching and fixing the applique unit pattern, Kirgiz people also carefully stitched the bright decorative yarns at the joint place of the pattern, so that on one hand, the applique pattern of the joint place can be reinforced, and on the other hand, the decorative yarns are used to form a sharp outline to the pattern, thus creating a strong visual effect. Different from ordinary ethnic groups' stitching embroidery, Kirgiz women often choose two colored yarn with opposite twist directions when stitching the applique decoration line of Shyrdaks. One of them is $S$ direction and the other is $\mathrm{Z}$ direction, put the two together at the joint place of applique to form the decorative traces of the herringbone pattern, and the front and back of the stitching patterns are shown in "Fig. 7". Normally after the unit pattern is patched, they stitches decoration yarns on the surface first and then apply the overall blanket.
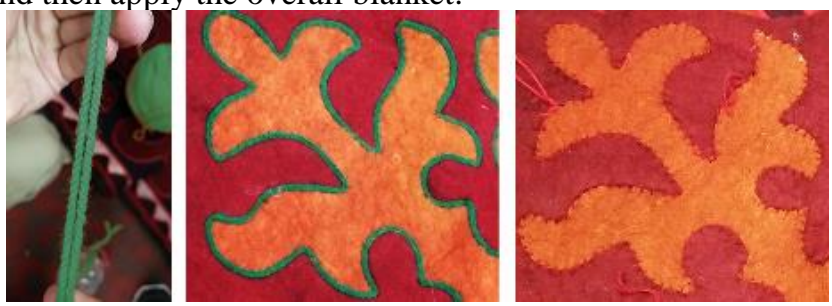

Fig. 7. Stitching technique of Shyrdaks.

6) Blanket decoration: After completing the fixing of the applique topping pattern unit and stitching the decorating yarn, all the unit pattern combinations are arranged and stitched into a large surface felt. When the seams are stitched, the pattern stitching of the center main area is completed first, and at the joint place, the herringbone pattern decoration yarns similar to the applique topping are also stitched. Some are also sewn with black and white and other zweifarbig wavy lines or jagged lines. The narrow bands are also commonly used around the main pattern area, they are about $10 \mathrm{~cm}$ wide and have the same length with the main pattern area. Black-andwhite felt are made by the baste stitches and the applique stitches are made afterwards. Around the main pattern area enclosed by the zweifarbig narrow decorative strips, matching patterns are appliqued together, and the outer side of the main area is often decorated with similar narrow wave line bands with black and white colors. It is often sewn with a colored woollen braided rope as a decoration at the edge of the felt. "Fig. 8" shows the sewn Shyrdak. 


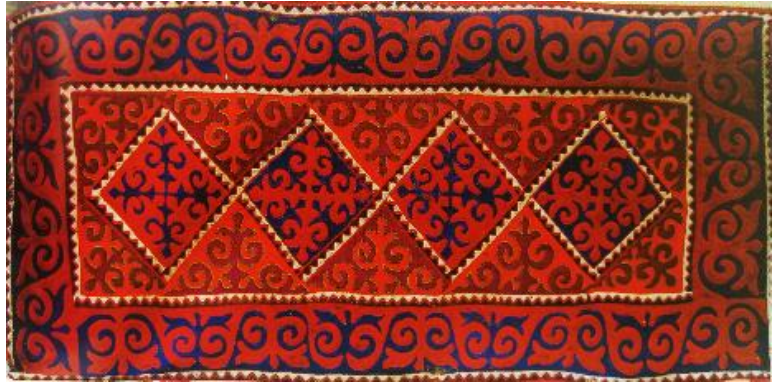

Fig. 8. Shyrdaks surface felt after the seam has completed.

\section{Suture Surface Blanket and Floor Blanket}

After the whole surface felt has been sewn together, it must be stitched together with the pre-made floor blanket. When suture them, thin thread is penetrate the surface felt and the floor felt with crochet hooks, because the yarn is thin and the stitches are small, so the surface of the felt leaves only a series of fine needle tracking. Generally along the outline of the decorative pattern in its inside and outside, suture a clear round stitching seams respectively, not only has the function of fixation and durability enhancement, but also form the decoration effect of a beautiful smooth stitches and concaveconvex surface. After the suture is finished, the edge of the surface felt and floor felt should be over-seamed with basket stitches, so that the edge of the blanket does not come off during long-term use, as shown in "Fig. 9". A Shyrdak with this kind of applique, not only looks colorful, but also very durable, it can be used for decades.
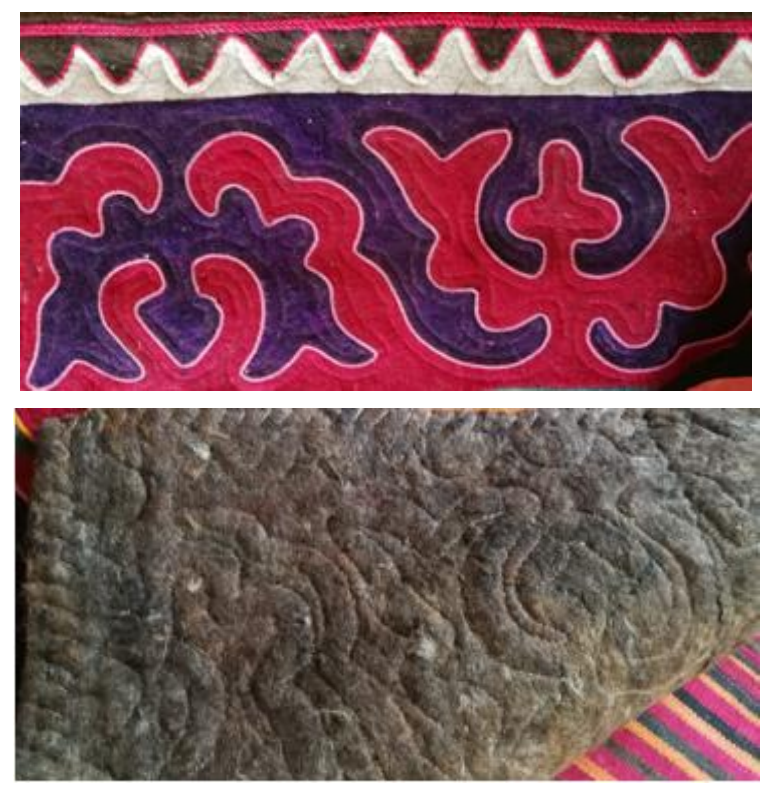

Fig. 9. Shyrdak after suture the surface and floor blanket together.

\section{PATTERN ART OF SHYRDAKS}

\section{A. Common Patterns}

As Kirgiz's folk songs sang: "I made the cloud-like Shyrdak, the pattern of blossoming flowers represent the girl's heart, embroiders the mountains and rivers in my hometown, and embroiders herds on the hillside. The beautiful Shyrdak is embroidered with flowers, the pattern of blossoming flowers represent the girl's heart, embroiders the mountain eagles and horses, under the blue sky there lives happy Kirgiz people".[5] The nomadic lifestyle accumulated over the thousands of years determined the patterns on the Shyrdaks of Kirgiz people are mostly based on animals, plants, natural landscapes, etc. in nature. Kirgiz people use the pictographic approach of "observing objects and extract images"[6] to record common objects in nomadic life in Shyrdak's patterns with their unique ways. Patterns are mainly symmetric composition, and the common patterns include beast horn pattern such as antlers, antelope horns, ox horns, etc.; Bird patterns such as mountain eagles, wild geese, pigeons, etc.; Plant patterns such as flowers, fruits, vines etc.; Weapon patterns such as arrows, spears, halberds; And natural landscape patterns such as mountains, rivers and clouds as shown in "Table I". 
TABLE I. COMMON PATTERNS USED By KIRGIZ's SHYRDAKS [7]

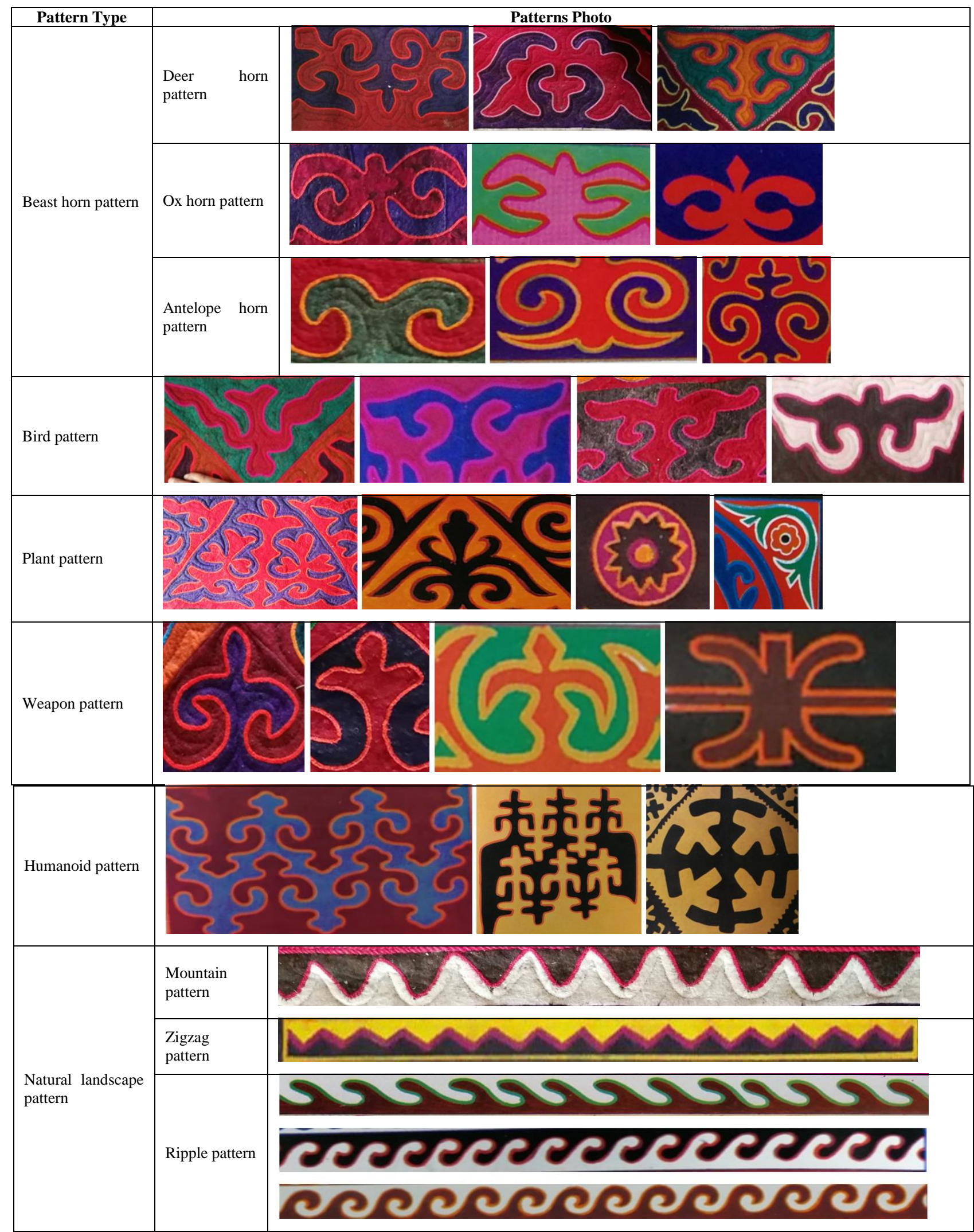


In the aspect of pattern application, Kirgiz people particularly like the symmetrical and balanced beauty of order. The geometric arrangement of skeletons is their aesthetic tradition that has been passed down from thousands of years. They like to turn the common patterns up and down, left and right symmetrically to form the main flower pattern in the center of Shyrdaks. They also like to arrange the pattern of the elements in a row to form a two-side continual pattern, which is used as a match pattern around the main area. The mountain pattern, ripple pattern and other zweifarbig colored ribbons are used to decorate the seams at the joint place. These patterns, which have been formed through long-term practice, are extremely rich in compositional changes, and because their beauty and order are derived from a similar coil winding method, so that most patterns are richly configurable. These mellow and full curves and thick horn shapes become the most recognizable cultural gene in the Kirgiz patterns.

The Shyrdaks with rich colors and rich patterns is just like an unfolding scroll that shows a wonderful picture of Kirgiz people's love of life. However, the survey also found that many patterns of Shyrdaks have gradually diluted the original meaning in the process of oral and hand communication, resulting in the producers themselves cannot explain the original meaning of the pattern, they only rely on accumulated experience draws the pattern, and the meaning of the pattern itself is no longer in question. The record of the Shyrdak patterns and their implied meanings needs to be carried out urgently.

\section{B. Layout}

The layout of the Shyrdaks pattern can be divided into two main categories: the center main pattern area and the surrounding match pattern area. The main pattern area in the center uses rhombuses, squares, or triangles as the basic pattern unit, and is arranged in geometric skeleton applique topping shape. The arrangement methods mainly include rhombic arrangement, square arrangement, cross arrangement, and triangular arrangement, among which rhombic arrangement are the most common in application. Based on them, multi-layer rhombic arrangement with more pattern changes and richer colors has been developed to create beautiful decorative effects. "Fig. 10" shows several common central area layouts.

Around the main area, two groups of horizontal patterns are used to form horizontally and vertically arranged strip as a surrounding decoration. Generally, two patterns are complementary to each other in the up and down, left and right strip areas, commonly used patterns include deer horn, ox horn, antelope horn and other beast horn patterns. In addition to the horizontal stripe layout, there are triangles in the surrounding area, which can be seen in horizontal and vertical layouts. "Fig. 11 " shows some typical peripheral layouts. The area between main pattern area and the surrounding area are usually decorated with black mountain and white river or other zweifarbig colored ripple pattern or zigzag pattern strips. This narrow strip is often decorated outside the unit pattern of main pattern area to form a strong decoration effect.
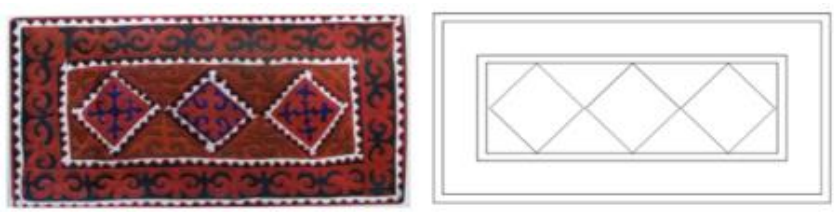

Rhombus
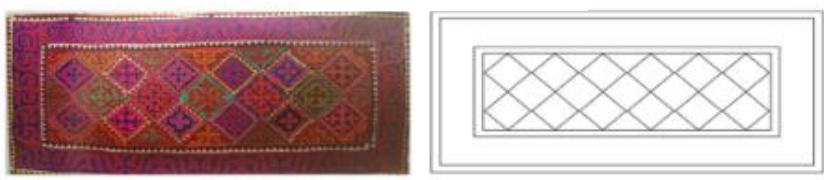

Multi-layer rhombus
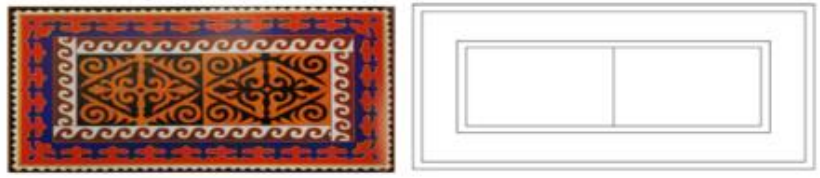

Chequered

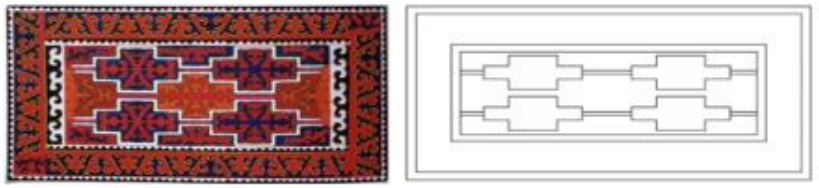

Cross-shaped
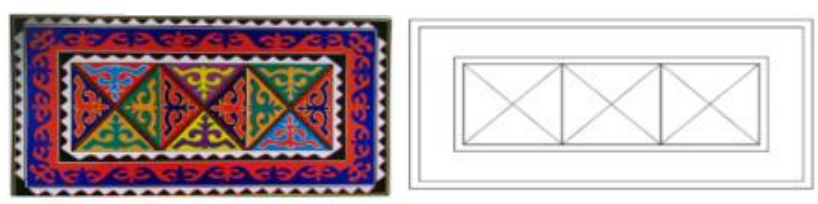

Triangular

Fig. 10. Layout of Shyrdaks' Main pattern area.
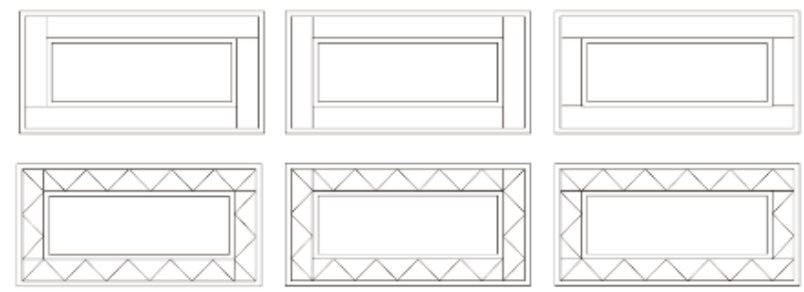

Fig. 11. Layout of Shyrdaks' surrounding pattern area.

\section{Cultural CONNOTATION OF SHYRDAKS}

The Kirgiz's Shyrdaks has profound cultural connotations. First of all, the Kirgiz's Shyrdaks is inherited and developed from ancient Xinjiang felt techniques and has a long history. The earliest felt products unearthed in Xinjiang are the plaid blankets dating back more than 3,000 years, found in the Wupu cemetery of Hami, and dyed felt products were found in cemeteries such as Zhagunluke and Shanpula. As an ancient nomadic people with a history of more than 2,000 years, the Kirgiz people were active in the history stage in the Qin and 
Han dynasties, with the title of "Jian Kun". They have mastered the technique of producing felts very early and have been passed down till now through people's labor practices, so that it has developed into today's Shyrdaks felt products that are applique and inlay through the exchange of cut patterns and background, itself is the material carrier of the Kirgiz's historical civilization. Secondly, Shyrdaks is one of the most important home textiles of the Kirgiz people, so it is of great importance to Kirgiz's daily life. Kirgiz women studied Shyrdaks' craftsmanship since childhood and used Shyrdaks as a must-have item for women's wedding dowry. [12] A Shyrdak can be used for decades and it carries the rise and fall of the Kirgiz family, also it is a symbol of Kirgiz women's talent and family wealth. Thirdly, Shyrdaks' craft is complicated, time-consuming and labor-consuming. One family's production normally required the help from many other families. It is often seen a scene that a group of Kirgiz women sit in circle on a sunny day making Shyadak while chatting. Therefore, Shyrdaks is also the crystallization of the wisdom of the masses and mapped the optimism and solidarity spirit of the Kirgiz people. In addition, the patterns of Shyrdaks are all came from Kirgiz's "observe objects and extract image", and they embroider the most common scenes in life on the colorful felt, with vivid color contrasts and rich animal and plant patterns. The patterns not only reflect its long-standing nomadic tradition, but also embody the aesthetic psychology of Kirgiz people who love nature and life.

\section{CONCLUSION}

This paper discusses the characteristics of Shyrdaks used by Kirgiz people in Xinjiang, China. It includes the production process, patterns, colors, and cultural connotations of it. Through investigation and analysis, it is known that Shyrdak is a traditional national felt product formed by the accumulation of long-term history of Kirgiz ethnic group in Xinjiang, China. Its production process is mainly through the method of applique and color topping to stitch various colored felt pattern together to form the strong decorative effect which patterns embedded in each other and colors complemented with each other. The varied patterns and rich and beautiful colors make Shyrdaks become a beautiful landscape in Kirgiz family. However, with the development of the market economy, new urban lifestyle has had a tremendous impact on traditional handicrafts of this ethnic group. Kirgiz's Shyrdak technique is facing a gradual decline. How to protect and inherit this traditional handicraft skill of the nation in the new wave of the times and give it new features of the era is a problem that needs to be solved urgently.

\section{REFERENCES}

[1] Xin Xiaoyu, Bian Xiangyang:"A Preliminary Study on the Development of Xinjiang Traditional Felt Making Process" [J], "Wool Spinning Technology" No. 2, 2015, P. 66. 信晓瑜, 市向阳: 《新疆传统制毡工 艺发展初探》 $[\mathrm{J}]$, 《毛纺科技》, 2015 年第 2 期, 第 66 页.

[2] Chen Weiji: "The History of Chinese Textile Science and Technology (Ancient Part)" [M], Beijing: Science Press, 1984, P. 398. 陈维稷: 《中国纺织科学技术史 (古代部分) 》 $[\mathrm{M}]$, 北京: 科学出版社, 1984，第 398 页.
[3] Han Lianyun: "Illustrated book of Xinjiang Folk Arts" [M], Urumqi: Xinjiang People's Publishing Company, 2006, P. 196-201. 韩连叒: 《图说新疆民间工艺》 $[\mathrm{M}]$, 乌鲁木齐：新疆人民出版社，2006,第 196-201 页.

[4] Wan Xueyu: "An Analysis of the Kirgiz' Colored Felt"[J]. Journal of Xinjiang Arts University, No.3 2010, P. 15. 万雪玉: 《柯尔克孜族花 毡探析》[J].新疆艺术学院学报, 2010 年第 3 期, 第 15 页,

[5] Zhang Guanghan: "Colorful Handicrafts.Colored Felt [A]". He Jihong etc. Mysterious Western Holy Land [M]. Artush: Kezilesu Kirgiz Publishing Company, 1994: 155, quoted from Wan Xueyu, "An Analysis of the Kirgizcolored felt"[J]. Journal of Xinjiang Arts University, No. 3, 2010, P. 17 张光汉: 《异彩纷呈的手工艺品·花段 $[\mathrm{A}]\rangle$.贺继宏等.神秘的西部圣土 $[\mathrm{M}]$. 阿图什:克孜勒苏柯尔克孜文 出版社, 1994: 155, 转引自万雪玉《柯尔克孜族花毡探析》[J].新 疆艺术学院学报, 2010 年第 3 期, 第 17 页

[6] Wang Fan, Seligek Shati: "The Art of "Baina" - The Wonderful flower of Kirghiz Folk Art"[J]. Journal of Xinjiang Arts University, No.4,2012, P.9. 王凡,赛力克江.沙提: 《“百纳”工艺一一柯尔克孜民间织绣艺 术的奇㴰》 [J]. 新疆艺术学院学报,2012 第 4 期, 第 9 页,

[7] According to the field investigation and the published data, Liu Dingling: "Kirgiz Pattern Collection" [M], Beijing: National Publishing Company, 1990, P. 1-12; 根据田野调查和已出版资料整理, 参见刘 定陵: 《柯尔克孜族图案集》 $[\mathrm{M}]$, 北京：民族出版社，1990，第 112 页;

[8] Muthite Mai Maitiniya, Tursunjiang Abdullah Yimu: "Patterns for felt and wool carpet" [M]. Kashgar: Kashgar Uyghur Publishing Company, 2010, P.98 穆合特尔·麦麦提尼亚孜, 吐尔逊江・阿布都热依木: 《毡子花毡线毯花纹图案》 $[\mathrm{M}]$. 喀什: 喀什维吾尔文出版社, 2010 , 第 98 页

[9] Jumalaiyi Yu Suzheng, etc.: "Folk Pattern Collection of Kirgiz" (Kirgiz, English, Chinese) [M], Urumqi: Xinjiang People's Publishing Company, 1985,P. 146. 居玛来依・玉素甫等: 《柯尔克孜民间图案集》 (柯、英、汉文对照) [M],乌鲁木齐: 新疆人民出版社, 1985, 第 146 页.

[10] Zhang Hengde, Han Lianfen: "Xinjiang Folk Fine Arts Series - Folk Carpet" [M]. Urumqi: Xinjiang Fine Arts Photography Press, 2006, P 20 张亨德, 韩莲芬: 《新疆民间美术丛书——民间毡毯》 [M].乌鲁 木齐: 新疆美术摄影出版社, 2006, 第 20 页;

[11] Jumalaiyi YYu Suzheng, etc.: "Folk Pattern Collection of Kirgiz" (Kirgiz, English, Chinese) $[\mathrm{M}]$, Urumqi: Xinjiang People's Publishing Company, 1985，P. 148. 居玛来依・玉素甫等: 《柯尔克孜民间图案集》 （柯、英、汉文对照）[M],乌鲁木齐: 新疆人民出版社, 1985, 第 148 页.

[12] Adiji Jumatuerdi: "Enter the Chinese Ethnic Minorities Series - Kirgiz" [M], Shenyang: Liaoning National Publishing Company, 2015,P. 103. 阿地里- 居玛吐尔地: 《走进中国少数民族丛书—柯尔克孜族》 [M],沈阳：辽宁民族出版社，2015，第 103 页， 